\title{
A Contribution to the Estimation of Binary Halide and Pseudo-Halide Equilibrium Constants using a Linear Extrapolation Methodology
}

\author{
Astréa F. de S. Silva, ${ }^{* a}$ Manuel M. Ortega, ${ }^{\sharp, b}$ Cristo B. Melios, ${ }^{c}$ Leonardo Pezza, ${ }^{c}$ \\ Mercedes de Moraes, ${ }^{c}$ Mário Alberto Tenan ${ }^{d}$ and André F. Oliveira ${ }^{a}$
}

${ }^{a}$ Núcleo de Ciências Ambientais, Universidade de Mogi das Cruzes, UMC, Av. Cândido Xavier de Almeida Souza, 200, Centro Cívico, 08780-911 Mogi das Cruzes-SP, Brazil

${ }^{b}$ Departamento de Química, UFMA, 65085-580 São Luís-MA, Brazil

${ }^{c}$ Instituto de Química, UNESP, 1480-970 Araraquara-SP, Brazil

${ }^{d}$ Instituto de Física Gleb Wataghin, Universidade Estadual de Campinas-UNICAMP, 13083-970 Campinas-SP, Brazil

\begin{abstract}
$\mathrm{O}$ coeficiente de atividade molar individual do íon fluoreto $\left(\mathrm{y}_{\mathrm{F}}\right)$ foi determinado a $25^{\circ} \mathrm{C}$ para valores de força iônica entre 0,100 and 3,00 $\mathrm{mol} \mathrm{L}^{-1}\left(\mathrm{NaClO}_{4}\right)$ usando-se um eletrodo íon-seletivo. A dependência do coeficiente de atividade com a força iônica é explicada pela equação $\Phi_{\mathrm{F}}=\log y_{\mathrm{F}}=0,2315 I-0,041 I^{2}$. A função $\Phi_{\mathrm{F}}(\mathrm{I})$, foi associada a outras funções estimadas em trabalhos anteriores, por exemplo, $\Phi_{\mathrm{Cu}}(\mathrm{I})$ para cobre, e $\Phi_{\mathrm{H}}(\mathrm{I})$ para íon hidrogênio, possibilitando a estimativa de constantes de estabilidade estequiométricas e termodinâmicas tanto para equilíbrios de protonação de alguns haletos e pseudo-haletos como para as constantes de formação de complexos 1:1 de metais bivalentes com fluoreto e pseudo-haletos. O procedimento de cálculo proposto é consistente com dados experimentais criticamente selecionados da literatura. Verificou-se que é possível usar $\Phi_{\mathrm{F}}(\mathrm{I})$ na previsão de parâmetros de equilíbrio termodinâmicos independentemente do caráter HSAB de Pearson.
\end{abstract}

The molar single ion activity coefficient $\left(\mathrm{y}_{\mathrm{F}}\right)$ of fluoride ions was determined at $25{ }^{\circ} \mathrm{C}$ and ionic strengths between 0.100 and $3.00 \mathrm{~mol} \mathrm{~L}^{-1} \mathrm{NaClO}_{4}$ using an ion-selective electrode. The activity coefficient dependency on ionic strength was determined to be $\Phi_{\mathrm{F}}=\log y_{\mathrm{F}}=0.2315 I-0.041 I^{2}$. The function $\Phi_{\mathrm{F}}(\mathrm{I})$, combined with functions obtained in previous work for copper $\left(\Phi_{\mathrm{Cu}}\right)$ and hydrogen $\left(\Phi_{\mathrm{H}}\right)$, allowed us to make the estimation of the stoichiometric and thermodynamic protonation constants of some halides and pseudo-halides as well as the formation constants of some pseudo-halides and fluoride 1:1 bivalent cation complexes. The calculation procedure proposed in this paper is consistent with critically-selected experimental data. It was demonstrated that it is possible to use $\Phi_{\mathrm{F}}(\mathrm{I})$ for predicting the thermodynamic equilibrium parameters independently of Pearson's hardness of acids and bases.

Keywords: thermodynamic activity, ion-selective electrode analysis, stability constants

\section{Introduction}

The stoichiometric and thermodynamic constants for both protonation and complexation equilibria are parameters of fundamental importance. The development of reliable empirical methods for the estimations and/ or evaluations of these parameters is equally relevant. ${ }^{1-6}$

*e-mail: astrea@umc.br

\# In memoriam
Furthermore, the most common procedures for finding the thermodynamic values for protonation or complexation equilibria are based on graphical extrapolations to zero ionic strength of stoichiometric values of $\log \mathrm{K}_{\mathrm{H}}(\operatorname{or} \log \beta)$ or on complicated functions involving extended forms of the Debye-Hückel or Pitzer equations., ${ }^{57-9}$ The existing procedures are not reliable except in a few favorable cases. ${ }^{5,7}$ In some cases, the deviations obtained via common extrapolation methods can be as great as $400 \%,{ }^{8}$ however, the difficulties raised by the non-linear methodologies 
can be avoided by considering linear relationships, ${ }^{1-3}$ as explained below.

\section{The linear methodology}

The methodology is based on the following relation, which is valid for the metal-ligand formation equilibrium:

$\log \beta-\Phi_{M}-\Phi_{L}=\log \beta^{T}-\Phi_{M L}$

where $\mathrm{M}$ is a divalent metallic ion, $\mathrm{L}$ is a monovalent anionic ligand, ML is the first complex species formed, $\Phi_{\mathrm{M}}, \Phi_{\mathrm{L}}$ and $\Phi_{\mathrm{ML}}$ represent the functions of the single molar activity coefficients for the species, and $\beta^{\mathrm{T}}$ and $\beta$ are the thermodynamic and stoichiometric formation constants of $\mathrm{ML}$ at a given ionic strength. To simplify the notation, charges were omitted and only the formation of a 1:1 metalligand was considered.

The three terms on the left side of Eq. (1) can be calculated as functions of the ionic strength I of the medium. Furthermore, the values of $\log \beta$ can be found in the literature, ${ }^{12}$ whereas those for $\Phi_{\mathrm{M}}$ and $\Phi_{\mathrm{L}}$ can be calculated by taking into account the following empirical relation: ${ }^{10}$

$\Phi_{i}=\log y_{i}=a_{i} I^{0.5}+b_{i} I+c_{i} I^{1.5}+\ldots$

where $\mathrm{i}$ represents $\mathrm{M}$ or $\mathrm{L}, \mathrm{y}_{\mathrm{i}}$ is the molar activity coefficient of species $\mathrm{i}$, and $\mathrm{a}_{\mathrm{i}}, \mathrm{b}_{\mathrm{i}}, \mathrm{c}_{\mathrm{i}} \ldots$ are coefficients to be determined by considering extra-thermodynamic arguments. ${ }^{2,3}$ It should be noted that the necessity of getting information about the single-ion activities is not a problem, as recognized by Wilczek-Vera \& Vera, ${ }^{11}$ since the activity and hence the activity coefficient of a single ion can be calculated from ion-selective electrode measurements.

Since the sum Y of the three terms on the left side of Eq. (1) can be found as a function of I, the next step in the methodology consists of looking for a non-negative integer number $\mathrm{n}$ for which a plot of $\mathrm{Y}$ versus $\mathrm{I}^{\mathrm{n} / 2}$ becomes linear (in practice, $\mathrm{n}=1$ or 2 has been sufficient). From this linear fitting, it is possible to empirically determine the right side of Eq. (1); namely, the difference $\log \beta^{\mathrm{T}}-\Phi_{\mathrm{ML}}$.

In conclusion, the functions $\Phi_{i}(I)=\log y_{i}$, together with a sufficient number of stoichiometric $(\log \beta$, I) or $\left(\log \mathrm{K}_{\mathrm{H}}\right.$, I) pairs of values critically selected from the literature, ${ }^{12}$ allow us to find linear relations that provide a reliable extrapolation of the thermodynamic values $\log \beta^{\mathrm{T}}$ ( or $\log \mathrm{K}_{\mathrm{H}}^{\mathrm{T}}$ ), as well as the interconversion of stoichiometric values of $\log \beta\left(\right.$ or $\log \mathrm{K}_{\mathrm{H}}$ ) at different ionic strengths.

\section{Estimation of $\Phi_{i}(I)$ with potentiometric measurements}

Potentiometric measurements using metal or ligand ion-selective electrodes can be carried out in an inert electrolyte at constant ionic strength and temperature. The electromotive force of the potentiometric cell obeys the following simplified equation:

$E=E_{i}^{0^{\prime}}+S \log [i]$

where $\mathrm{i}$ represents an ion or a neutral substance, [i] is the molar concentration of species $\mathrm{i}, \mathrm{S}$ is a constant, and $E_{i}^{0^{\prime}}$ is the sum of all constant terms that contribute to the total measured electromotive force (reference electrode, liquid junction and indicator electrode potentials). The constant sum term can be expressed in terms of the activity coefficient $y_{\mathrm{i}}$ as:

$E_{i}^{0^{\prime}}=\left(E_{i}^{0^{\prime}}\right)_{0}+S \log y_{i}$

where $\left(E_{i}^{0^{\prime}}\right)_{0}$ is the infinite dilution limit value of $E_{i}^{0^{\prime}}$.

Equation (3) shows that $\mathrm{E}^{0}{ }_{\mathrm{i}}$ and $\mathrm{S}$ can be obtained graphically from the measured values of an $\mathrm{E}$ versus $\log$ [i] plot. From Eqs. (2) and (4), we obtain

$E_{i}^{0^{\prime}}=\left(E_{i}^{0^{\prime}}\right)_{0}+S\left(a_{i} \mathrm{I}^{0.5}+b_{i}^{\mathrm{I}}+c_{i} \mathrm{I}^{1.5}+\ldots\right)$

The experimental determination of sufficient pairs of values (I, $\mathrm{E}_{\mathrm{i}}^{0^{\prime}}$ ) makes it possible to estimate the parameter $\left(\mathrm{E}_{\mathrm{i}}^{0^{\prime}}\right)_{0}$ and the empirical coefficients $\mathrm{a}_{\mathrm{i}}, \mathrm{b}_{\mathrm{i}}, \mathrm{c}_{\mathrm{i}} \ldots$ from a polynomial fitting. The function $\Phi_{\mathrm{i}}=\log \mathrm{y}_{\mathrm{i}}$ may then be estimated.

\section{Experimental}

\section{Materials and Solutions}

Analytical-grade reagents were used in all experiments. A stock solution of sodium perchlorate was standardized by evaporation, drying, and constant weighing at $120^{\circ} \mathrm{C}$. The solution $\mathrm{pH}$ was measured with a glass electrode and varied between 6.80 and 7.00. The stock solution of perchloric acid was standardized with sodium carbonate. The sodium fluoride solution was prepared in a polyethylene volumetric flask, without previous reagent purification. All of the solutions were prepared with Milli-Q water.

\section{Instruments}

The potentiometric measurements were performed with a precision of $c a .0 .1 \mathrm{mV}$ using an Orion 940 potentiometer. 
The temperature was kept at $25.0 \pm 0.1^{\circ} \mathrm{C}$ using a Tecnal Scientific Appliances cryostat connected to a $35 \mathrm{~mL}$ titration cell with a thermostatization jacket. The internal glass surface of the titration cell was totally covered with a layer of paraffin to avoid fluoride attack. Metrohm E274 piston burettes (precision of $0.01 \mathrm{~mL}$ ) and automatic pipettes of $0.100 \pm 0.001 \mathrm{~mL}$ and $0.500 \pm 0.002 \mathrm{~mL}$ were used. The ionic strength was adjusted with $\mathrm{NaClO}_{4}$ over the 0.1-3.0 $\mathrm{mol} \mathrm{L}^{-1}$ range. An Orion 94-04 fluoride ionselective electrode and an Orion 90-01 single junction $\mathrm{Ag} / \mathrm{AgCl}$ reference electrode adequate for use in fluoride media were employed.

\section{Potentiometric Cell}

The potentiometric cell used for the $\mathrm{NaF}-\mathrm{NaClO}_{4}$ systems is

$\mathrm{Ag} / \mathrm{AgCl}\left|\begin{array}{l:l|l}\mathrm{NaCl} 0,01 \mathrm{~mol} / \mathrm{L} & \mathrm{NaF} \mathrm{c} \mathrm{mol} / \mathrm{L}_{\mathrm{NaClO}_{4}(\mathrm{I}-0,01) \mathrm{mol} / \mathrm{L}} & \mathrm{NaClO}_{4}(\mathrm{I}-\mathrm{c}) \mathrm{mol} / \mathrm{L}\end{array}\right| \mathrm{EIS}_{\mathrm{F}}$

\section{Procedure}

Solutions of $0.090 \mathrm{~mol} \mathrm{~L}^{-1} \mathrm{NaF}$ were prepared in $100.0 \mathrm{~mL}$ polyurethane volumetric flasks for each ionic strength. Using a piston burette Methrom E274, the necessary volumes of a $5.223 \mathrm{~mol} \mathrm{~L}^{-1} \mathrm{NaClO}_{4}$ solution and water were added to adjust the ionic strength of the $\mathrm{NaF}$ solution to the desired value.

The indicator and reference electrodes were placed in a cell containing $10.00 \mathrm{~mL}$ of $\mathrm{NaClO}_{4}$ at the given ionic strength. After stirring the $\mathrm{NaClO}_{4}$ solution for $10 \mathrm{~min}$, aliquots $(0.5$ or $0.1 \mathrm{~mL})$ of the $0.090 \mathrm{~mol} \mathrm{~L}^{-1} \mathrm{NaF}$ solution were added. The potential value was registered after $40 \mathrm{~s}$, which represents the time recommended by the manufacturer.

When not in use, the indicator electrode was kept in a $10^{-3} \mathrm{~mol} \mathrm{~L}^{-1}$ solution of $\mathrm{NaF}$. The single junction reference electrode was kept in $\mathrm{a} \mathrm{NClO}_{4}$ solution at the ionic strength of the next group of measurements to be carried out.

\section{Results and Discussion}

\section{Estimate of the fluoride ion activity coefficient dependency on the ionic strength of the medium}

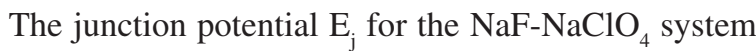
was evaluated with the help of the Henderson equation ${ }^{13}$ and molar ionic conductivity data from the literature. ${ }^{14}$ The resulting values obtained for $E_{j}$ were small enough to be neglected. The parameters $\mathrm{E}_{\mathrm{F}}^{0}$ and $\mathrm{S}$ were determined by simple linear regression. ${ }^{15}$ The correlation coefficient $\mathrm{r}$ was greater than 0.999 , in all cases. A variation of $c a .18 \mathrm{mV}$ in the $\mathrm{E}^{0^{3}}$ values and an average value of $59.7 \mathrm{mV} /$ decade for $\mathrm{S}$ were obtained in the interval of ionic strength considered (Electronic Supplementary Information).

The best fit ${ }^{1-3,16}$ obtained for the $\mathrm{E}^{\mathrm{o}^{\prime}}$ versus I curve was:

$E_{F}^{0^{\prime}}=(-317.7 \pm 0.3)+(13.82 \pm 0.6) I-(2.47 \pm 0.2) I^{2}$

with a correlation coefficient of 0.8897 and a standard deviation of 2.34. Considering the average experimental value of $\mathrm{S}(59.7 \pm 1.4 \mathrm{mV} /$ decade), it can be verified that the dependency of $\mathrm{y}_{\mathrm{F}}$ on the ionic strength of the $\mathrm{NaF}^{-\mathrm{NaClO}_{4}}$ system at $25.0 \pm 0.1^{\circ} \mathrm{C}$ is given by:

$\Phi_{F}=\log y_{F}=0.2315 I-0.041 I^{2}$

The influence of the electrolyte on the molar activity coefficient of $F^{-}$is highly significant. These results indicate that structural effects of the solvent as well as ion-ion and ion-solvent interactions (hydration) should be taken into account to produce a realistic description of these systems. The sodium ion produces a weak-ordering effect on the structure of water. In contrast, the perchlorate ion plays a significant role in promoting a disordering effect on the water structure. The significant variations in the activity coefficients of fluoride in the sodium perchlorate media due to an increase in the ionic strength can be at least partially justified by the perchlorate ion disordering effect. Similar behavior was observed for $\mathrm{H}^{+}$, copper(II), cadmium(II), and lead(II) in a sodium perchlorate medium. ${ }^{1}$ An exception was the acetate ion, in which case no significant change was observed probably due to the fact that the ordering effect compensates that caused by the perchlorate ion. ${ }^{1}$

\section{Estimates of the thermodynamic equilibrium constants for some equilibria in aqueous solutions}

The function $\Phi_{\mathrm{F}}(\mathrm{I})$ determined in the present paper was used in connection with the functions $\Phi_{\mathrm{Cu}}(\mathrm{I})$, $\Phi_{\mathrm{Cd}}(\mathrm{I}), \Phi_{\mathrm{Pb}}(\mathrm{I})$ and $\Phi_{\mathrm{H}}(\mathrm{I})$ obtained by Pezza and coworkers $^{1-3}$ for the same conditions of temperature, ionic strength and ionic medium. The proposed methodology was applied for the estimation of the thermodynamic constants for the mono-protonation $\left(\log \mathrm{K}_{\mathrm{H}}{ }^{\mathrm{T}}\right)$ of halides or pseudo-halides (HX species), as well as the formation of (1:1) bivalent metal complexes $\left(\log \beta^{\mathrm{T}}\right)$ with halides $\left(\mathrm{MF}^{+}\right)$or pseudo-halides $\left(\mathrm{MX}^{+}\right.$species $)$.

The corresponding linear relations for the calculation of the thermodynamic constants for the $\mathrm{HX}, \mathrm{MF}^{+}$and 
$\mathrm{MX}^{+}$systems were established from sufficient pairs of stoichiometric values $\left(\log \mathrm{K}_{\mathrm{H}}, \mathrm{I}\right)$ or $(\log \beta, \mathrm{I})$ critically selected from the literature. ${ }^{12}$

The empirical coefficients $\mathbf{a}$ and $\mathbf{b}$ in equation 2 are listed in Tables 1-3 for the HX, $\mathrm{MF}^{+}$and $\mathrm{MX}^{+}$systems. Also listed are the experimental conditions and the corresponding equations established.

The estimated values of $\log \mathrm{K}_{\mathrm{H}}{ }^{\mathrm{T}}$ and $\log \beta^{\mathrm{T}}$ (Tables 2 and 3) are consistent with the experimental data critically selected in the literature, ${ }^{12}$ showing the comprehensiveness of the proposed methodology in predicting the thermodynamic constants. It was also verified that it is possible to use $\Phi_{\mathrm{F}}(\mathrm{I})$ in predicting $\log \beta^{\mathrm{T}}$ for complexes of other halides and pseudo-halides (electronic supplementary information), independently of the hard and soft acids/ bases classification. ${ }^{17}$

\section{Other Successful Applications of the Linear Methodology}

Figure 1 compares the plots of $\log \beta$ and $\log \beta-\Phi_{\mathrm{Cu}}-\Phi_{\mathrm{F}}$ as functions of the ionic strength $\mathrm{I}$ for the complexes $\mathrm{PbBr}^{+}$and $\mathrm{SnCl}^{+}$. In contrast to the linear extrapolation of $\log \beta-\Phi_{\mathrm{Cu}}-\Phi_{\mathrm{F}}$ to zero ionic strength, the degree of uncertainty in the non-linear extrapolation of $\log \beta$ is very high. The same behavior was observed in the cases of $\mathrm{CoF}^{+}, \mathrm{MgF}^{+}, \mathrm{CoCl}^{+}, \mathrm{NiCl}^{+}, \mathrm{NiN}_{3}^{+}, \mathrm{PbCl}^{+}$and $\mathrm{PbNCS}^{+}$. These cases are clear examples of the inherent advantage of the linear methodology in providing reliable estimations of thermodynamic constants via extrapolation.
In some cases, it can be observed that although one point deviates noticeably from the linear relation (e.g. Fig 2), the remaining points lead to stability constant values that agree with those reported in the literature. ${ }^{12}$ These results suggest further investigation of these systems, since the values of $\log \beta$ for the deviant points could probably be in error.

Another striking example of the effectiveness of the linear extrapolation is presented by the $\mathrm{PbNCS}^{+}$system (see Fig. 3). The linear extrapolation predicts for the thermodynamic constant a value of 0.69 with an uncertainty of $c a .0 .07$ (electronic supplementary information). In contrast, a non-linear fitting hardly leads to a reliable thermodynamic value based on the three stoichiometric values available in the literature. ${ }^{12}$

The linear methodology was also applied to the calculation of the thermodynamic stability constants of the $\mathrm{CoF}^{+}, \mathrm{MnF}^{+}, \mathrm{PbF}^{+}, \mathrm{PbNCS}^{+}, \mathrm{CdF}^{+}, \mathrm{MnF}^{+}, \mathrm{CdN}_{3}{ }^{+}, \mathrm{NiCl}^{+}$, $\mathrm{NiN}_{3}{ }^{+}$and $\mathrm{ZnN}_{3}{ }^{+}$systems, for which the corresponding values have not been reported in the literature. ${ }^{12}$

Another very interesting finding is that with just the two values of $\log \beta$ available for the $\mathrm{CaF}^{+}$and $\mathrm{HgN}_{3}^{+}$ systems, it was possible to obtain thermodynamic values compatible with those found in the literature. Moreover, the parameters $\Phi_{\mathrm{Cu}}$ and $\Phi_{\mathrm{F}}$ were used successfully to correlate stoichiometric constants determined at ionic strengths outside the experimental range considered in this work, namely 0.05 or $4.00 \mathrm{~mol} \mathrm{~L}^{-1}$, for the $\mathrm{CuF}^{+}, \mathrm{UO}_{2} \mathrm{~F}^{+}, \mathrm{CdCl}^{+}$, $\mathrm{PbBr}^{+}, \mathrm{PbCl}^{+}, \mathrm{PbNCS}^{+}, \mathrm{SnBr}^{+}, \mathrm{SnCl}^{+}, \mathrm{ZnNCS}^{+}$and $\mathrm{CuN}_{3}^{+}$ systems.

Table 1. $\log \beta_{\mathrm{T}}$ and $\Phi_{\mathrm{MF}}{ }^{+}$estimates for some $\mathrm{MF}^{+}$complexes in aqueous solution at $\mathrm{T}=25^{\circ} \mathrm{C}$

\begin{tabular}{|c|c|c|c|c|c|c|c|}
\hline \multirow[t]{2}{*}{ System $\mathrm{MF}^{+}$} & \multirow{2}{*}{$\begin{array}{l}\text { I range/ } \\
\left(\mathrm{mol} \mathrm{L}^{-1}\right)^{\mathrm{a}}\end{array}$} & \multirow[t]{2}{*}{$\mathrm{n}^{\mathrm{b}}$} & \multicolumn{2}{|c|}{$\log \beta^{\mathrm{T}}$} & \multirow{2}{*}{$\Phi_{\mathrm{MF}}^{+} / \mathrm{I}$} & \multirow[t]{2}{*}{$r^{2}$} & \multirow[t]{2}{*}{$10^{3} \mathrm{sd}$} \\
\hline & & & this work & literature & & & \\
\hline \multirow[t]{2}{*}{$\mathrm{CuF}^{+}$} & $0.05-3$ & 3 & {$[1.27 \pm 0.02$} & $(1.2)(\mathrm{c})$ & $0.32 \pm 0.01$ & 0.9988 & 12 \\
\hline & & 8 & $1.26 \pm 0.05]$ & & $0.35 \pm 0.03$ & 0.9587 & 90 \\
\hline \multirow[t]{2}{*}{$\mathrm{NiF}^{+}$} & $1-3$ & 3 & {$[1.18 \pm 0.02$} & 1.2 & $0.43 \pm 0.01$ & 0.9994 & 15 \\
\hline & & 5 & $1.09 \pm 0.05]$ & & $0.40 \pm 0.02$ & 0.9865 & 52 \\
\hline \multirow[t]{2}{*}{$\mathrm{ZnF}^{+}$} & $0.5-3$ & 3 & {$[1.22 \pm 0.02$} & 1.15 & $0.40 \pm 0.01$ & 0.9989 & 14 \\
\hline & & 6 & $1.26 \pm 0.02$ & & $0.42 \pm 0.01$ & 0.9986 & 21 \\
\hline \multirow[t]{2}{*}{$\mathrm{CoF}^{+}$} & $1-3$ & 3 & {$[1.18 \pm 0.02$} & $*$ & $0.43 \pm 0.01$ & 0.9994 & 15 \\
\hline & & 4 & $1.24 \pm 0.13$ & & $0.47 \pm 0.05$ & 0.9757 & 88 \\
\hline $\mathrm{UO}_{2} \mathrm{~F}^{+}$ & $0.5-4$ & 4 & $4.91 \pm 0.05$ & $*$ & $0.33 \pm 0.02$ & 0.9927 & 53 \\
\hline $\mathrm{NpO}_{2} \mathrm{~F}^{+}$ & $0.1-2$ & 3 & $4.46 \pm 0.04$ & 4.60 & $0.29 \pm 0.04$ & 0.9836 & 52 \\
\hline $\mathrm{PbF}^{+}$ & $1-2$ & 4 & $2.27 \pm 0.06$ & $*$ & $0.69 \pm 0.05$ & 0.9911 & 40 \\
\hline $\mathrm{CdF}^{+}$ & $0.8-3$ & 4 & $1.09 \pm 0.02$ & $*$ & $0.47 \pm 0.01$ & 0.9991 & 21 \\
\hline $\mathrm{BeF}^{+}$ & $0.5-1$ & 2 & 5.7 & $5.92(d)$ & 0.51 & & \\
\hline $\mathrm{CaF}^{+}$ & $0.5-1$ & 2 & 1.10 & 1.1 & 0.36 & & \\
\hline \multirow[t]{2}{*}{$\mathrm{MgF}^{+}$} & $0.1-1$ & 3 & $1.77 \pm 0.00$ & $1.8(\mathrm{e})$ & $0.29 \pm 0.01$ & 0.9997 & 3 \\
\hline & & & & $2.05(\mathrm{f})$ & & & \\
\hline
\end{tabular}

a: ionic strength (I) adjusted with $\mathrm{NaClO}_{4}$; b: number of pairs $(\log \beta, \mathrm{I})$ taken from reference 12; c: doubtful value according to reference 12; d: estimated by Brown \& Sylva ${ }^{19}$; e: value given in volume 4 , reference 12 ; f: value given in volume 6 , reference $12 ; *$ not available; sd = standard deviation 
Table 2. $\log \beta \mathrm{T}$ and $\Phi_{\mathrm{MX}}{ }^{+}$estimates for some $\mathrm{MX}^{+}$complexes in aqueous solution at $\mathrm{T}=25^{\circ} \mathrm{C}^{*}$

\begin{tabular}{|c|c|c|c|c|c|c|c|}
\hline \multirow[t]{2}{*}{ System } & \multirow{2}{*}{$\begin{array}{l}\text { I range/ } \\
\left(\mathrm{mol} \mathrm{L}^{-1}\right)^{\mathrm{a}}\end{array}$} & \multirow[t]{2}{*}{$\mathrm{n}^{\mathrm{b}}$} & \multicolumn{2}{|c|}{$\log \beta^{\mathrm{T}}$} & \multirow[t]{2}{*}{$\Phi_{\mathrm{MX}}+$} & \multirow[t]{2}{*}{$\mathrm{r}^{2}$} & \multirow[t]{2}{*}{$10^{3} \mathrm{sd}$} \\
\hline & & & Literature [12] & this work & & & \\
\hline $\mathrm{MnSCN}^{+}$ & $0.5-3$ & 3 & $1.23(\mathrm{~d}) ; 1.31(\mathrm{e})$ & $1.32 \pm 0.06$ & $0.48 \pm 0.03$ & 0.9949 & 64 \\
\hline $\mathrm{NiCl}^{+}$ & $1-3$ & 3 & (f) & $0.94 \pm 0.09$ & $0.78 \pm 0.04$ & 0.9974 & 57 \\
\hline $\mathrm{NiN}_{3}^{+}$ & $1-3$ & 3 & (f) & $1.42 \pm 0.06$ & $0.44 \pm 0.03$ & 0.9995 & 42 \\
\hline $\mathrm{NiNCS}^{+}$ & $0.5-3$ & 3 & $1.76-0.09$ & $1.73 \pm 0.03$ & $0.44 \pm 0.02$ & 0.9988 & 29 \\
\hline $\mathrm{PbBr}^{+}$ & $0.5-4$ & 5 & $1.77 \pm 0.1$ & $1.60 \pm 0.03$ & $0.40 \pm 0.01$ & 0.9967 & 38 \\
\hline $\mathrm{PbCl}^{+}$ & $0.5-4$ & 5 & $1.59 \pm 0.02$ & $1.44 \pm 0.01$ & $0.40 \pm 0.01$ & 0.9996 & 14 \\
\hline $\mathrm{PbNCS}^{+}$ & $2-4$ & $3(\mathrm{c})$ & (f) & $0.69 \pm 0.07$ & $0.27 \pm 0.02$ & 0.9927 & 33 \\
\hline $\mathrm{PbI}^{+}$ & $1-3$ & 3 & $1.92 \pm 0.1$ & $1.66 \pm 0.19$ & $0.31 \pm 0.09$ & 0.9239 & 127 \\
\hline $\mathrm{SnBr}^{+}$ & $1-4$ & 4 & $1.16 \pm 0.05$ & $1.28 \pm 0.13$ & $0.48 \pm 0.05$ & 0.9800 & 109 \\
\hline $\mathrm{SnCl}^{+}$ & $0.5-4$ & 5 & 1.51(d); & $1.56 \pm 0.04$ & $0.41 \pm 0.01$ & 0.9961 & 43 \\
\hline $\mathrm{ZnN}_{3}^{+}$ & $0.1-1$ & 2 & (f) & 1.40 & 0.51 & - & - \\
\hline $\mathrm{ZnNCS}^{+}$ & $1-4$ & 4 & 0.5 & $0.58 \pm 0.07$ & $0.49 \pm 0.03$ & 0.9948 & 58 \\
\hline $\mathrm{CdBr}^{+}$ & $0.1-3$ & 6 & $2.14 \pm 0.02$ & $2.12 \pm 0.01$ & $0.43 \pm 0.01$ & 0.9983 & 21 \\
\hline $\mathrm{CdCl}^{+}$ & $0.1-4$ & 6 & $1.98 \pm 0.03$ & $1.91 \pm 0.01$ & $0.41 \pm 0.003$ & 0.9998 & 10 \\
\hline $\mathrm{CdI}^{+}$ & $0.5-3$ & 4 & $2.28 \pm 0.1$ & $2.40 \pm 0.01$ & $0.39 \pm 0.004$ & 0.9998 & 8 \\
\hline $\mathrm{CdN}_{3}^{+}$ & $2-3$ & 2 & (f) & 1.68 & 0.32 & - & - \\
\hline $\mathrm{CdNCS}^{+}$ & $0.1-3$ & 6 & 1.89 & $1.89 \pm 0.02$ & $0.46 \pm 0.01$ & 0.9999 & 28 \\
\hline $\mathrm{CoCl}^{+}$ & $1-3$ & 3 & (f) & $0.74 \pm 0.04$ & $0.63 \pm 0.02$ & 0.9990 & 28 \\
\hline $\mathrm{CoNCS}^{+}$ & $0.1-2$ & 4 & $1.72 \pm 0.2$ & $1.74 \pm 0.01$ & $0.63 \pm 0.01$ & 0.9995 & 15 \\
\hline $\mathrm{CuN}_{3}^{+}$ & $0.1-4$ & 3 & $2.86\left(20^{\circ} \mathrm{C}\right)$ & $2.76 \pm 0.0002$ & $0.41 \pm 0.001$ & 0.99998 & 31 \\
\hline $\mathrm{CuNCS}^{+}$ & $0.1-3$ & 3 & 2.33 & $2.23 \pm 0.02$ & $0.41 \pm 0.01$ & 0.9993 & 23 \\
\hline $\mathrm{CuNO}_{3}^{+}$ & $1-4$ & 4 & 0.5 & $0.58 \pm 0.07$ & $0.49 \pm 0.03$ & 0.9948 & 58 \\
\hline $\mathrm{HgCl}^{+}{ }^{3}$ & $0.5-3$ & 3 & 7.30 & $7.23 \pm 0.01$ & $0.36 \pm 0.01$ & 0.9996 & 13 \\
\hline $\mathrm{HgN}_{3}^{+}$ & $0.1-1$ & 2 & 7.80 & 7.77 & 0.64 & - & - \\
\hline
\end{tabular}

$* \Phi_{\mathrm{M}}=\Phi_{\mathrm{Cu}}$ (estimated by Pezza and co-workers) ${ }^{1,2}$; a: ionic strength (I) adjusted with $\mathrm{NaClO}_{4}$; b: numbers of pairs (log $\beta$, I) taken from reference 12; c: value related to coordination with $\mathrm{N}$; d: value given in vol. 4, ref. 12; e: value given in vol. 5, ref.12; f: not available; sd = standard deviation.

Table 3: Values of $\log \beta$ as calculated by Eq. 8 for $\mathrm{I}=0.7 \mathrm{~mol} \mathrm{~L}^{-1}\left(\mathrm{NaClO}_{4}\right)$, compared with those given by Martell ${ }^{18}$, for soluble components of the sea water (electrolyte: $\mathrm{NaCl}$, Temperature: $25^{\circ} \mathrm{C}$ )

\begin{tabular}{|c|c|c|c|c|}
\hline \multirow[t]{2}{*}{ System } & \multirow[t]{2}{*}{$b^{*}$} & \multirow{2}{*}{$\begin{array}{c}\log \beta^{\mathrm{T}} \\
\text { this work }\end{array}$} & \multicolumn{2}{|c|}{$\log \beta$ for $I=0.7 \mathrm{M}$} \\
\hline & & & this work & Martell $^{18}$ \\
\hline $\mathrm{HgCl}^{+}$ & 0.36 & 7.23 & 6.74 & 6.73 \\
\hline $\mathrm{CdF}^{+}$ & 0.47 & 1.09 & 0.52 & 0.50 \\
\hline $\mathrm{CdBr}^{+}$ & 0.43 & 2.12 & 1.58 & 1.50 \\
\hline $\mathrm{PbCl}^{+}$ & 0.40 & 1.44 & 0.92 & 0.90 \\
\hline $\mathrm{PbBr}^{+}$ & 0.40 & 1.60 & 1.08 & 1.08 \\
\hline $\mathrm{PbF}^{+}$ & 0.69 & 2.27 & 1.55 & 1.40 \\
\hline $\mathrm{CaF}^{+}$ & 0.36 & 1.10 & 0.61 & 0.6 \\
\hline $\mathrm{MgF}^{+}$ & 0.29 & 1.77 & 1.33 & 1.30 \\
\hline $\mathrm{MnF}^{+}$ & 0.38 & 1.22 & 0.71 & 0.70 \\
\hline $\mathrm{CuF}^{+}$ & 0.32 & 1.27 & 0.81 & 0.80 \\
\hline $\mathrm{UO}_{2} \mathrm{~F}^{+}$ & 0.33 & 4.91 & 4.44 & 4.4 \\
\hline $\mathrm{CdCl}^{+}$ & 0.41 & 1.91 & 1.38 & 1.35 \\
\hline $\mathrm{HF}$ & 0.32 & 3.16 & 2.94 & 2.95 \\
\hline $\mathrm{ZnF}^{+}$ & 0.40 & 1.22 & 0.70 & 0.7 \\
\hline $\mathrm{NiF}^{+}$ & 0.43 & 1.18 & 0.64 & 0.5 \\
\hline $\mathrm{NiCl}^{+}$ & 0.78 & 0.94 & 0.15 & -0.1 \\
\hline
\end{tabular}

$\log \beta=\log \beta^{\mathrm{T}}-\mathrm{b} \mathrm{I}+\Phi_{\mathrm{M}}+\Phi_{\mathrm{X}}$ where $\Phi_{\mathrm{M}}=\Phi_{\mathrm{Cu}}$ e $\Phi_{\mathrm{X}}=\Phi_{\mathrm{F}} ; * \mathrm{~b}$ values from Tables 1-2
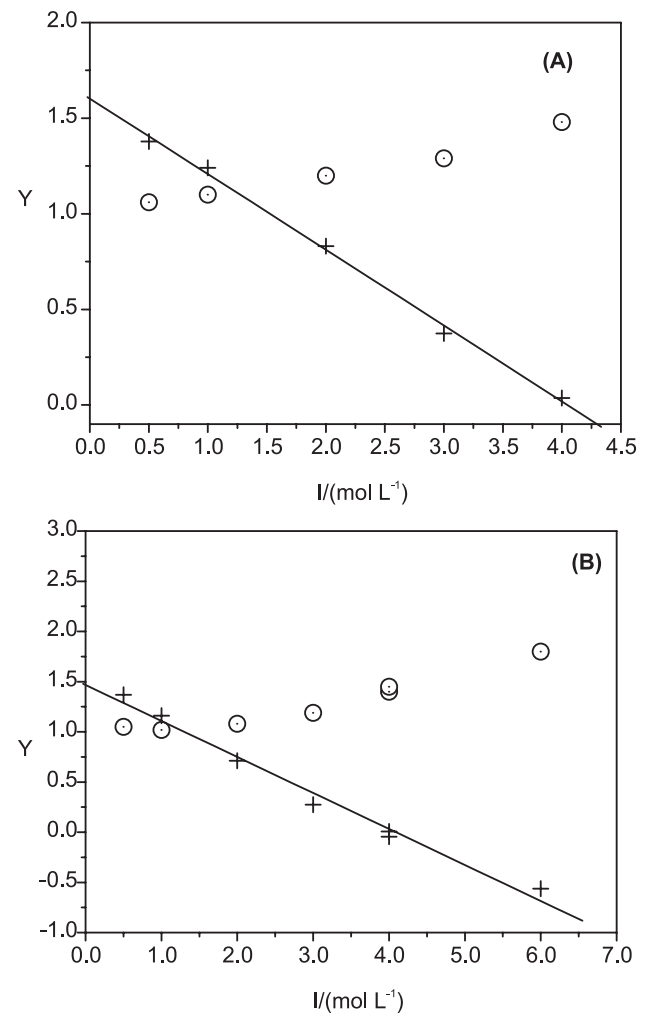

Figure 1. Plots of (o) $\mathrm{Y}=\log \beta$ and $(+) \mathrm{Y}=\log \beta-\Phi_{\mathrm{Cu}}-\Phi_{\mathrm{F}}$, as functions of the ionic strength I, for (A) the $\mathrm{PbBr}^{+}$system and (B) the $\mathrm{SnCl}^{+}$system. 


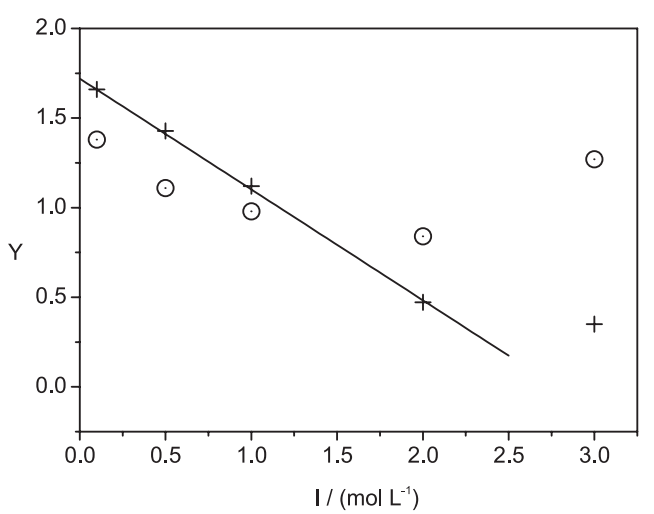

Figure 2. Plots of (o) $Y=\log \beta$ and $(+) Y=\log \beta-\Phi_{\mathrm{Cu}}-\Phi_{\mathrm{F}}$, as functions of the ionic strength I, for the CoNCS ${ }^{+}$system.

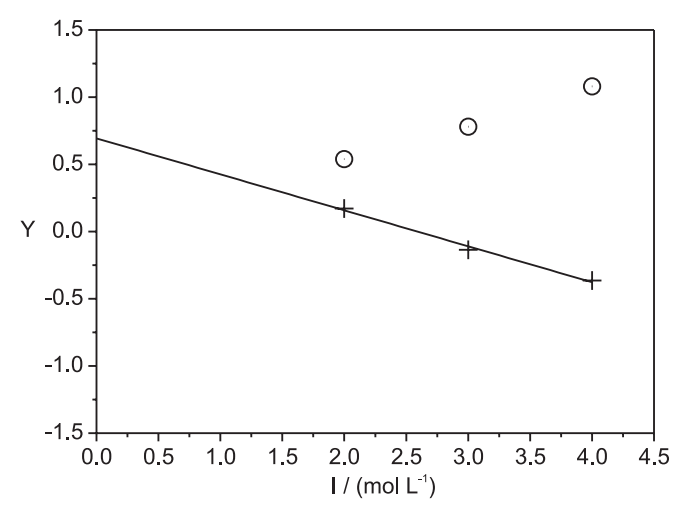

Figure 3. Plots of (o) $Y=\log \beta$ and $(+) Y=\log \beta-\Phi_{\mathrm{Cu}}-\Phi_{\mathrm{F}}$, as functions of the ionic strength $\mathrm{I}$, for the $\mathrm{PbNCS}^{+}$system.

A useful feature of this methodology is that its effectiveness in the prediction of stability constants is not limited to systems for which the parameter $\Phi_{\text {Metal }}$ is available. Good estimates were obtained for several complexes of other divalent metallic ions besides $\mathrm{Cu}^{2+} ;$ namely, $\mathrm{Fe}^{2+}, \mathrm{Co}^{2+}$, $\mathrm{Ni}^{2+}, \mathrm{Zn}^{2+}, \mathrm{Be}^{2+}, \mathrm{Ca}^{2+}, \mathrm{Mn}^{2+}, \mathrm{Sn}^{2+}, \mathrm{Pb}^{2+}, \mathrm{Cd}^{2+}$, and $\mathrm{Hg}^{2+}$. This provides some support for the consideration that similar ions should present similar equilibrium parameters. ${ }^{1-4}$ It is worth emphasizing that the function $\Phi_{\mathrm{F}}$ associated with the fluoride ion provided good results for the protonation and stability constants for various metal complexes with halides such as $\mathrm{Cl}^{-}, \mathrm{Br}^{-}$, and $\mathrm{I}^{-}$, and pseudo-halides such as $\mathrm{CN}^{-}, \mathrm{SCN}^{-}, \mathrm{N}_{3}^{-}$, $\mathrm{NO}_{3}^{-}$and $\mathrm{NO}_{2}^{-}$(see Tables 1-3).

\section{Application of the methodology in speciation of some $M X^{+}$ soluble components in seawater}

The thermodynamic stability constants $\left(\log \beta^{\mathrm{T}}\right)$ and the empirical coefficients $\mathbf{b}$ determined for some $\mathrm{MX}^{+}$ species in $\mathrm{NaClO}_{4}$ media were used to calculate $\log \beta$ by considering $\mathrm{I}=0.7 \mathrm{~mol} \mathrm{~L}^{-1}$ in the following equation:

$\log \beta=\log \beta^{\mathrm{T}}-\mathrm{b} \mathrm{I}+\Phi_{\mathrm{M}}+\Phi_{\mathrm{x}}$, where $\Phi_{\mathrm{M}}=\Phi_{\mathrm{Cu}}$ and $\Phi_{\mathrm{X}}=\Phi_{\mathrm{F}}$. As shown in Table 3, the results are in good agreement with those critically selected by Martell ${ }^{18}$ for the $\mathrm{MX}^{+}$species in seawater (supporting electrolyte $\mathrm{NaCl}$ at $\mathrm{I}=0.7 \mathrm{~mol} \mathrm{~L}^{-1}$ and $\mathrm{T}=25^{\circ} \mathrm{C}$ ). The exceptions are the results for $\mathrm{NiF}^{+}$and $\mathrm{NiCl}^{+}$. Although different supporting electrolytes were considered $\left(\mathrm{NaClO}_{4}\right.$ in the present work and $\mathrm{NaCl}$ from Martell), the very good agreement obtained for the majority of cases (thirteen species) suggests that the values of the stoichiometric constants given by Martell ${ }^{18}$ for the two exceptional cases $\left(\mathrm{NiF}^{+}\right.$and $\left.\mathrm{NiCl}^{+}\right)$should be reviewed.

\section{Conclusions}

The possibility of using $\Phi_{\mathrm{F}}$ to predict $\log \beta^{\mathrm{T}}$ for complexes of other halides and pseudo-halides, independently of the classification of the hard and soft acids and bases, has been clearly demonstrated. This result is certainly one of the most significant contributions of this work.

Furthermore, the analysis in this paper extends the usefulness of the methodology proposed previously. ${ }^{2}$ As noted by Pezza et al., ${ }^{2}$ it is possible to use $\Phi_{\mathrm{Cu}}$ to predict the equilibrium parameters related to other metallic ions such as $\mathrm{Pb}$ and $\mathrm{Cd}$. In this investigation, the methodology has been successfully applied to several other metallic ions.

The satisfactory results obtained in the speciation of some components of seawater for $\mathrm{I}=0.7 \mathrm{~mol} \mathrm{~L}^{-1}$ show that this methodology can contribute to the determination of parameters of essential importance in the study and speciation of chemical systems such as biological fluids, soils, and natural and supply waters.

In conclusion, the variety of cases analyzed in this paper form a sound basis for the effectiveness of the linear methodology in providing reliable estimations of equilibrium constants for several binary systems in aqueous media.

\section{Acknowledgements}

The authors are indebted to the Brazilian Foundations CNPq, CAPES, FAPESP and FAEP/UMC.

\section{Suplemmentary Information}

Suplemmentary data are available free of charge at http://jbcs.sbq.org.br, as pdf file.

\section{References}

1. Pezza, L.; Molina, M.; Moraes, M. de; Melios, C. B.; Tognolli, J. O.; Talanta 1996, $43,1689$. 
2. Pezza, L.; Molina, M.; Moraes, M. de; Melios, C. B.; Gomes, H. M.; Tognolli, J. O; Talanta 1996, 43, 1697.

3. Pezza, L.; Molina, M.; Moraes, M. de; Melios, C. B.; Tognolli, J. O.; Int. J. Environ. Anal. Chem. 1997, 68, 295.

4. Anderegg, G.; Kholeif, S.; Talanta 1994, 41, 1507.

5. Partanen, J. I.; Juusola, P. M.; Vahteristo, K. P.; Mendonça, A. J. G.; J. Solution Chem. 2007, 36, 39.

6. Hancock, R. D.; Analyst 1997,122, 51R.

7. Rossotti, F.J.; Rossotti, H.; The Determination of Stability Constants, McGraw Hill: New York, 1961.

8. Beck, T.; Nagypál, I.; Chemistry of Complex Equilibria, Wiley: New York, 1990.; Grenthe, I.; Wanner, H.; TB-52 Guidelines for the Extrapolation to Zero Ionic, OECD Nuclear Energy Agency: Issy-les-Moulineaux, 2000.

9. Hartley, F.R.; Burguess, C., Alcock, R.; Solution Equilibria, Wiley: New York, 1980.

10. Gordon, J. E.; The Organic Chemistry of Electrolyte Solutions; Wiley: New York, 1975.

11. Wilczek-Vera, G.; Vera, J.H.; Fluid Phase Equilibr. 2005, 236, 96.; Rodil, E.; Vera, J. H.; Fluid Phase Equilibr. 2003, 205, 115; Zhuo, Z. , Dong, W., Wang, W. , Wang; Fluid Phase Equilibr. 2008, 274, 80 .
12. Martell, A.E.; Smith, R.M.; Critical Stability Constants Vols.3-6, Plenum: New York, 1976, 1977, 1982, 1989.

13. Henderson, P.; Z. Phys. Chem. 1907, 59, 118 apud Harris, D.C.; Quantitative Chemical Analysis, 2nd ed., W.H. Freeman \& Co.: New York, 1992.

14. Parsons, R.; Handbook Electrochemical Constants, Butterworths: London, 1959.

15. Oliveira, A.F.; Silva, A. F. S.; Molina, M.; Abstracts of the XI CIBAE-IX SIBEE, Águas de Lindóia, Brasil, 1994.

16. Microcal Software; Microcal Origin, Northampton, USA, 1994.

17. Huheey, J.E.; Inorganic Chemistry - Principles of Structure and Reactivity, 3rd ed., Harper \& Row: New York, 1983.; Reed, J. L.; Inorg. Chem. 2008, 47, 5591.

18. Martell, A.E.; Motekaitis, R.J.; Smith, R.M. In Environmental Inorganic Chemistry; Ingolic, K.J.; Martell, A.E., eds., Verlag Chemie: Florida, 1985.

19. Brown, P.; Sylva, J.; J. Chem. Res. 1987, S , 4; Brown, P.; Sylva, J.; J. Chem. Res. 1987, M, 110.

Received: June 11, 2009

Web Release Date: October 23, 2009

FAPESP helped in meeting the publication costs of this article. 


\title{
A Contribution to the Estimation of Binary Halide and Pseudo-Halide Equilibrium Constants using a Linear Extrapolation Methodology
}

\author{
Astréa F. de S. Silva, ${ }^{*, a}$ Manuel M. Ortega ${ }^{\sharp, b}$ Cristo B. Melios, ${ }^{c}$ Leonardo Pezza, \\ Mercedes de Moraes, ${ }^{c}$ Mário Alberto Tenan ${ }^{d}$ and André F. Oliveira ${ }^{a}$ \\ ${ }^{a}$ Núcleo de Ciências Ambientais, Universidade de Mogi das Cruzes, Av. Cândido Xavier de Almeida \\ Souza, 200, Centro Cívico, 08780-911 Mogi das Cruzes-SP, Brazil \\ ${ }^{b}$ Departamento de Química, UFMA, 65085-580 São Luís-MA, Brazil \\ ${ }^{c}$ Instituto de Química, UNESP, 1480-970 Araraquara-SP, Brazil \\ ${ }^{d}$ Instituto de Física Gleb Wataghin, Universidade Estadual de Campinas-UNICAMP, \\ 13083-970 Campinas-SP, Brazil
}

Table S1. Calibration Parameters for the $\mathrm{NaF}_{-} \mathrm{NaClO}_{4}$ System at $(25.0 \pm 0.1){ }^{\circ} \mathrm{C}$ in the linear $\mathrm{pF}$ interval $(3.05-1.28)$

\begin{tabular}{lcccc}
\hline $\mathrm{I} /\left(\mathrm{mol} \mathrm{L}^{-1}\right)$ & $\left(\mathrm{E}_{\mathrm{i}}^{0^{\prime}} \pm \mathrm{sd}\right) /(\mathrm{mV})$ & $(\mathrm{S} \pm \mathrm{sd}) /(\mathrm{mV} / \mathrm{dec})$ & $\mathrm{r}$ & $\mathrm{SSR}$ \\
\hline 0.1 & $-312.6 \pm 0.4$ & $59.8 \pm 0.2$ & 0.99981 & 0.069 \\
0.3 & $-310.0 \pm 0.7$ & $57.8 \pm 0.4$ & 0.99989 & 0.368 \\
0.5 & $-306.8 \pm 0.2$ & $61.1 \pm 0.2$ & 0.99994 & 0.838 \\
1.0 & $-302.9 \pm 0.5$ & $58.0 \pm 0.2$ & 0.99991 & 0.522 \\
1.5 & $-299.3 \pm 0.4$ & $61.4 \pm 0.2$ & 0.99980 & 11.729 \\
2.0 & $-296.5 \pm 0.2$ & $59.8 \pm 0.1$ & 0.99993 & 3.915 \\
2.5 & $-295.1 \pm 0.1$ & $60.3 \pm 0.3$ & 0.99999 & 0.282 \\
3.0 & $-294.9 \pm 0.2$ & $59.8 \pm 0.1$ & 0.99996 & 0.258 \\
\hline
\end{tabular}

$\mathrm{sd}=$ standard deviation; $\mathrm{r}=$ correlation coefficient; $\mathrm{SSR}=$ sum of squared residues 